\title{
PENGARUH GAYA KEPEMIMPINAN TERHADAP KINERJA KARYAWAN DAN DAMPAKNYA TERHADAP LOYALITAS KARYAWAN
}

\author{
Kurnia Tri Jayanti ${ }^{1}$, Lela Nurlaela Wati ${ }^{2}$ \\ ${ }^{1}$ STIE Muhammadiyah Jakarta, kurniatj28@gmail.com \\ ${ }^{2}$ STIE Muhammadiyah Jakarta, lela@ stiemj.ac.id
}

\begin{abstract}
ABSTRAK
Penelitian ini bertujuan untuk menganalisis bukti empiris pengaruh gaya kepemimpinan terhadap kinerja karyawan dan dampaknya terhadap loyalitas karyawan pada PT. Fastrata Buana Cabang Pulogadung. Sampel yang diperoleh sebanyak 187 responden, teknik pengambilan sample menggunakan purposive sampling, yaitu teknik pengambilan sample yang memberikan peluang yang sama bagi setiap unsur (anggota) populasi untuk dipilih menjadi anggota sample. Teknik pengumpulan data menggunakan kuesioner, teknik analisis data yang digunakan adalah validitas dan reliabilitas. Hasil penelitian ini menunjukan bahwa terdapat pengaruh positif dan signifikan antara gaya kepemimpinan dan terhadap kinerja karyawan, gaya kepemimpinan berpengaruh positif dan signifikan terhadap loyalitas karyawan, kinerja karyawan berpengaruh positif dan signifikan terhadap loyalitas karyawan, serta terdapat pengaruh positif dan signifikan antara gaya kepemimpinan terhadap loyalitas karyawan melalui kinerja karyawan.
\end{abstract}

Kata Kunci: Kinerja Karyawan, Gaya Kepemimpinan, Loyalitas Karyawan

\begin{abstract}
The research aims to analyze empirical evidence of the influence of leadership style on employee performance and its impact on employee loyalty on PT. Fastrata Buana Branch Pulogadung. Samples obtained by 187 respondents, sample retrieval techniques using purposive sampling, namely sample retrieval techniques that provide equal opportunities for each element (member) of the population to be selected to be a sample member. Data collection techniques using questionnaires, data analysis techniques used are validity and reliability. The results of this study show that there is a positive and significant influence between leadership styles and on employee performance, leadership styles have positive and significant influence on employee loyalty, employee performance has positive and significant influence on employee loyalty, as well as a positive and significant influence between leadership styles on employee loyalty through employee performance.
\end{abstract}

Keywords: Employee Performance, Leadership Style, Employee Loyalty 


\section{PENDAHULUAN}

Pada berbagai bidang khususnya kehidupan berorganisasi, faktor manusia merupakan masalah utama disetiap kegiatan yang ada didalamnya. Organisasi merupakan kesatuan sosial yang dikoordinasikan secara sadar dengan sebuah batasan yang reaktif dapat diidentifikasikan, bekerja secara terus menerus untuk mencapai tujuan (Robbins, 2006). Semua tindakan yang diambil dalam setiap kegiatan diprakarsai dan ditentukan oleh manusia yang menjadi anggota perusahaan. Perusahaan membutuhkan adanya faktor sumber daya manusia yang potensial baik pemimpin maupun karyawan pada pola tugas dan pengawasan yang merupakan penentu tercapainya tujuan perusahaan.

Perusahaan tidak hanya membutuhkan sumber daya manusia yang cakap dan terampil, tetapi perusahaan juga membutuhkan karyawan yang giat bekerja untuk mencapai hasil kerja yang maksimal. Selain itu perusahaan juga membutuhkan karyawan yang mampu bekerja sama baik antara karyawan dengan karyawan maupun karyawan dengan atasan (pemimpin).

Salah satu dari aktivitas perusahaan dipengaruhi oleh system pola hubungan yang terjadi di dalamnya, baik hubungan dengan sesama karyawan maupun hubungan dengan atasan. Pola hubungan yang terjadi antara atasan dengan bawahan dapat menyebabkan karyawan merasa senang atau tidak senang bekerja di perusahaan tersebut, untuk itulah dalam organisasi atau perusahaan selalu dilakukan perencanaan pengelolaan sumber daya manusia untuk mendapatkan orang yang tepat untuk jabatan yang tepat. Salah satu sasaran pengelolaan sumber daya manusia pada fungsi manajemen organisasi adalah menyangkut masalah kepemimpinan, seseorang yang ditunjuk sebagai pemimpin maupun yang di akui oleh anggota sebagai seseorang yang pantas memimpin mereka, dialah yang menjalankan fungsi organisasi tersebut. Cara dan pola tingkah laku pemimpin diartikan oleh bawahan yang bekerja sama dengannya sebagai gaya kepemimpinan (Guntoro, 2015).

Menurut Rivai (2004), kepemimpinan (leadership) adalah proses mempengaruhi atau memberi contoh kepada pengikut-pengikutnya melalui proses komunikasi dalam upaya mencapai tujuan organisasi. Dalam sebuah kepemimpinan ada gaya kepemimpinan yang diharapkan dapat memajukan perusahaan dan mensejahterakan karyawan. Setiap pemimpin memiliki cara memimpin yang berbeda yang disebut dengan gaya kepemimpinan. Gaya kepemimpinan yang baik dilakukan untuk meningkatkan kinerja karyawan. Pemimpin yang baik tidak akan ada tanpa bawahan yang baik, begitu pula sebaliknya. Antara pimpinan dan bawahan saling membutuhkan untuk bersinergi menjadikan perusahaan semakin maju.

Seorang pemimpin dalam organisasi atau perusahaan harus dapat menciptakan integrasi yang serasi dengan para bawahannya juga termasuk dalam membina kerja sama, mengarah dan mendorong gairah kerja para bawahan sehingga tercipta motivasi positif yang akan menimbulkan niat dan kinerja yang maksimal juga didukung fasilitas-fasilitas perusahaan untuk mencapai sasaran perusahaan. Dimana seorang pemimpin merupakan salah satu bagian dari manajemen dalam memainkan peran yang penting dalam mempengaruhi dan memberikan sikap serta perilaku individu dan kelompok, sehingga membentuk gaya kepemimpinan yang pemimpin terapkan (Guntoro, 2015).

PT. Fastrata Buana adalah perusahaan swasta yang bergerak dalam bidang distributor, berlokasi di Jl. Suci - ciracas, dan memiliki beberapa cabang di Jakarta, salah satunya adalah cabang Pulogadung yang akan diteliti oleh penulis. PT. Fastrata Buana cabang Pulogadung memiliki kurang lebih 187 karyawan, dan hampir 60\% karyawan sudah bekerja lebih dari 10 tahun. Setiap cabang PT. Fastrata Buana di pimpin pleh seorang Branch Manajer (BM).

Dari kajian diatas masih banyak permasalahan yang ditemui di perusahaan PT. Fastrata Buana cabang Pulogadung, yaitu masih banyaknya jumlah keterlambatan dan absensi karyawan, selain itu juga masih ada karyawan yang tidak menyelesaikan pekerjaannya tepat waktu. Permasalahan tersebut akan menjadi kendala yang cukup besar terhadap proses pencapaian tujuan perusahaan. 


\section{JURNAL EKOBIS: EKONOMI, BISNIS \& MANAJEMEN} Vol 9 Nomor 1 (2019)

Oleh karena itu, karyawan di tuntut untuk menyelesaikan tugas dan tanggung jawabnya secara efektif dan efisien, baik dalam segi pekerjaan maupun absensi dan jam kerja, serta melakukan peran dan fungsinya dan itu semua berhubungan liniear dan berhubungan positif bagi keberhasilan perusahaan tersebut.

Penelitian dalam hal gaya kepemimpinan ini sangat penting untuk peneliti lakukan, begitu juga permasalahan kinerja karyawan dan loyalitas karyawan yang masih aktif bekerja di perusahaan PT. Fastrata Buana cabang Pulogadung. Dari beberapa permasalahan yang terdapat di perusahaan PT. Fastrata Buana, peneliti hanya akan memfokuskan pada persoalan pengaruh gaya kepemimpinan terhadap kinerja karyawan dan dampaknya terhadap loyalitas karyawan.

Emilia Ika Andriyani (2016) melakukan penelitian mengenai "pengaruh gaya kepemimpinan terhadap kinerja karyawan" dan hasilnya gaya kepemimpinan berpengaruh positif terhadap kinerja karyawan, Abdilah (2011) juga melakukan penelitian mengenai "Analisis pengaruh gaya kepemimpinan dan motivasi kerja terhadap kinerja karyawan" dan hasilnya gaya kepemimpinan dan motivasi kerja berpengaruh positif terhadap kinerja karyawan, selain itu Bryan Johannes Tampi (2014) juga melakukan penelitian mengenai "Pengaruh gaya kepemimpinan dan motivasi terhadap kinerja karyawan PT. Bank Negara Indonesia, TBK (Regional Sales Manado)" dan hasilnya juga sama bahwa gaya kepemimpinan dan motivasi berpengaruh positif terhadap kinerja karyawan.

Namun berbeda dengan hasil penelitian yang dilakukan oleh Christian Yogi Pratama (2012) mengenai "Pengaruh gaya kepemimpinan otokratis terhadap kepuasan kerja PT. KAI mobil Indonesia (cabang Semarang) yang hasilnya bahwa gaya kepemimpinan otokratis berpengaruh negatif terhadap kepuasan kerja.

Berdasarkan latar belakang masalah yang telah diuraikan diatas, maka dianggap cukup penting untuk melakukan penelitian tentang "Pengaruh Gaya Kepemimpinan terhadap kinerja karyawan dan dampaknya terhadap loyalitas karyawan" (Studi kasus pada PT. Fastrata Buana Cabang Pulogadung).

\section{KAJIAN LITERATUR Loyalitas Karyawan}

Loyalitas merupakan konsep yang tampak mudah dibicarakan dalam konteks seharihari tetapi tetap menjadi sulit ketika dianalisis dalam banyak hal. Secara harfiah loyal berarti setia, atau loyalitas dapat diartikan sebagai suatu kesetiaan. Kesetiaan ini timbul dari kesadaran sendiri. Permasalahan mengenai loyalitas pegawai merupakan permasalahan yang akan selalu dihadapi oleh pihak manajemen instansi atau perusahaan, karena itu manajemen perlu mengetahui faktor-faktor yang mempengaruhi loyalitas pegawai tersebut. Faktor-faktor yang dapat mempengaruhi loyalitas pegawai tersebut akan membuat manajemen instansi atau perusahaan dapat mengambil berbagai kebijakan yang diperlukan, sehingga dapat meningkatkan loyalitas pegawainya agar sesuai dengan harapan perusahaan. untuk mencapai prestasi kerja yang efektif bagi perusahaan loyalitas sangat berpengaruh terhadap prestasi kerja karyawan. Loyalitas merupakan suatu sikap yang timbul sebagai akibat keinginan untuk setia dan memperbaiki baik itu pada pekerjaannya, kelompok, atasan maupun pada perusahaannya. hal ini menyebabkan seseorang berkorban demi memuaskan pihak lain atau masyarakat. keinginan seseorang berbakti inilah yang membuat seseorang bekerja tanpa menghiraukan besarnya imbalannya tapi yang lebih penting lagi ialah hasil kerja yang menjadi prestasi kerjanya. Hal ini menyebabkan betapa pentingnya loyalitas karyawan untuk suatu perusahaan maupun instans (Safitri, 2015).

Karyawan yang memiliki loyalitas rendah terhadap perusahaan dapat mengganggu kinerja perusahaan, perusahaan tidak dapat mencapai target yang diharapkan. Rendahnya loyalitas karyawan dapat berdampak pada menurunnya produktivitas perusahaan, tingkat absen yang tinggi, dan ketidak patuhan karyawan terhadap atasan. Jika karyawan sudah tidak loyal 


\section{JURNAL EKOBIS: EKONOMI, BISNIS \& MANAJEMEN}

\section{Vol 9 Nomor 1 (2019)}

terhadap perusahaan, karyawan tersebut tidak memiliki gairah untuk bekerja secara maksimal dan cenderung tidak memiliki rasa tanggung jawab terhadap pekerjaan yang dilakukan. Rendahnya loyalitas dalam perusahaan sehingga dapat merusak visi dan tujuan perusahaan (Heni, 2010).

\section{Gaya Kepemimpinan}

Kepemimpinan pada dasarnya adalah kemampuan untuk mempengaruhi, menggerakkan dan mengarahkan suatu tindakkan pada seseorang atau kelompok untuk tujuan tertentu (Fuad, 2002). Dalam kenyataannya para pemimpin dapat mempengaruhi moral karyawan terutama tingkat prestasi suatu perusahaan. Untuk mencapai semua itu seorang pemimpin harus mempunyai kemampuan dan keterampilan kepemimpinan dalam melakukan pengarahan kepada bawahannya untuk mencapai tujuan suatu perusahaan. Gaya kepemimpinan adalah perilaku yang dilakukan dan ditunjukkan oleh seorang pemimpin di dalam memberikan pengarahan terhadap bawahannya dengan rasa mempercayai bawahan juga memuat bagaimana cara bekerjasama dengan bawahannya dalam mengambil keputusan, pembagian tugas dan wewenang, bagaimana cara berkomunikasi dan bagaimana hubungan diantara pemimpin dan bawahannya tersebut.

\section{Kinerja Karyawan}

Perilaku seorang pemimpin adalah pengaruh yang akan menimbulkan pemahaman tersendiri yang akan berpengaruh terhadap kondisi psikologis bawahan, ada bawahan yang melihat, mengamati dan meniru perilaku yang ditampilkan oleh pemimpin dalam melaksanakan pekerjaannya sesuai dengan harapannya. Apabila perilaku pemimpin yang ditampilkan dirasakan sebagai sesuatu yang diharapkan bawahan, maka akan memiliki dampak yang baik terhadap kinerja karyawan, sebaliknya apabila perilaku yang ditampilkan pemimpin sebagai sesuatu yang tidak sesuai dengan harapannya, maka akan berpengaruh kurang baik terhadap kinerja karyawan (Guntoro, 2015).

Oleh karena itu, untuk meningkatkan kembali kinerja karyawan, maka salah satu faktor yang harus diperhatikan adalah menyangkut gaya kepemimpinan yang diterapkan pemimpinpemimpin pada organisasi atau perusahaan yaitu bagaimana agar gaya kepemimpinan yang diterapkan para pemimpin dapat menunjang kinerja karyawannya agar menjadi lebih baik. Peningkatan kinerja karyawan dalam sebuah perusahaan sangatlah penting, karena akan berdampak positif bagi perusahaan dan diharapkan mampu meningkatkan keefektifan dan efesiensi perusahaan (Guntoro, 2015).

\section{PENGEMBANGAN HIPOTESIS \\ Hubungan Gaya Kepemimpinan terhadap Kinerja Karyawan}

Kepemimpinan pemimpin yang diperlihatkan dan diterapkan kedalam suatu gaya kepemimpinan merupakan salah satu faktor dalam meningkatkan kinerja karyawan, karena pada dasarnya sebagai tulang punggung pengembangan organisasi dalam mendorong dan mempengaruhi semangat kerja yang baik kepada bawahan. Untuk itu pemimpin perlu memikirkan dan memperlihatkan gaya kepemimpinan yang tepat dalam penerapannya (Tampi, 2014).

\section{Hubungan Loyalitas dengan Kinerja Karyawan}

Loyalitas adalah kesetiaan. Dan kesetiaan adalah kualitas yang menyebabkan kita tidak menggemingkan dukungan dan pembelaan kita kepada sesuatu. Loyalitaslah yang menyebabkan kita tetap membela seorang sahabat meski ia terancam harus masuk penjara. Loyalitaslah yang 


\section{JURNAL EKOBIS: EKONOMI, BISNIS \& MANAJEMEN} Vol 9 Nomor 1 (2019)

membuat kita menyanyi-nyanyi penuh semangat memberikan dukungan pada kesebelasan kesayangan kita, meski mereka sudah tertinggal beberapa gol dari tim lawan. Memang, loyalitas lebih banyak bersifat emosional. Loyalitas adalah kualitas perasaan dan perasaan tidak selalu membutuhkan penjelasan yang rasional.

Setiap perusahaan pasti ingin memiliki karyawan yang loyal. Mereka yang loyal di yakini dapat memberikan kontribusi yang maksimal dan selalu optimal dalam bekerja. Makanya dalam setiap test rekruitmen, penilaian loyal atau tidaknya karyawan seringkali menjadi pertimbangan penting. Perusahaan menilai loyalitas karyawan dari beberapa besar keterlibatan karyawan dalam bekerja untuk mencapai tujuan perusahaan. Karyawan yang selalu bekerja tanpa menuntut hak-hak yang semestinya di peroleh, dianggap sebagai karyawan teladan. Semakin banyak jam kerja karyawan dalam satu hari yang dihabiskan untuk perusahaan, maka karyawan tersebut dianggap memiliki tingkat loyalitas yang tinggi. Tetapi semakin "pas" jam kerja karyawan, maka karyawan tersebut dianggap biasa-biasa saja. Dan apabila karyawan yang datang terlambat di tempat kerja dan tidak menjadi masalah apakah pulang sesuai jam kerja kantor atau menyesuaikan jam pulang dengan jumlah waktu keterlambatan atau bahkan melebihi jumlah waktu keterlambatan, maka karyawan tersebut dianggap kurang loyal. Dan perusahaan cenderung mendorong karyawannya untuk kerja selama mungkin.

\section{Kerangka Pikir}

Kerangka pemikian menggambarkan hubungan antar Variabel, yaitu variabel independen (X) adalah Gaya Kepemimpinan, variable intervening ( $Y$ ) adalah Kinerja Karyawan, dan vaeriabel dependen (Z) adalah Loyalitas Karyawan. Sebagai berikut:

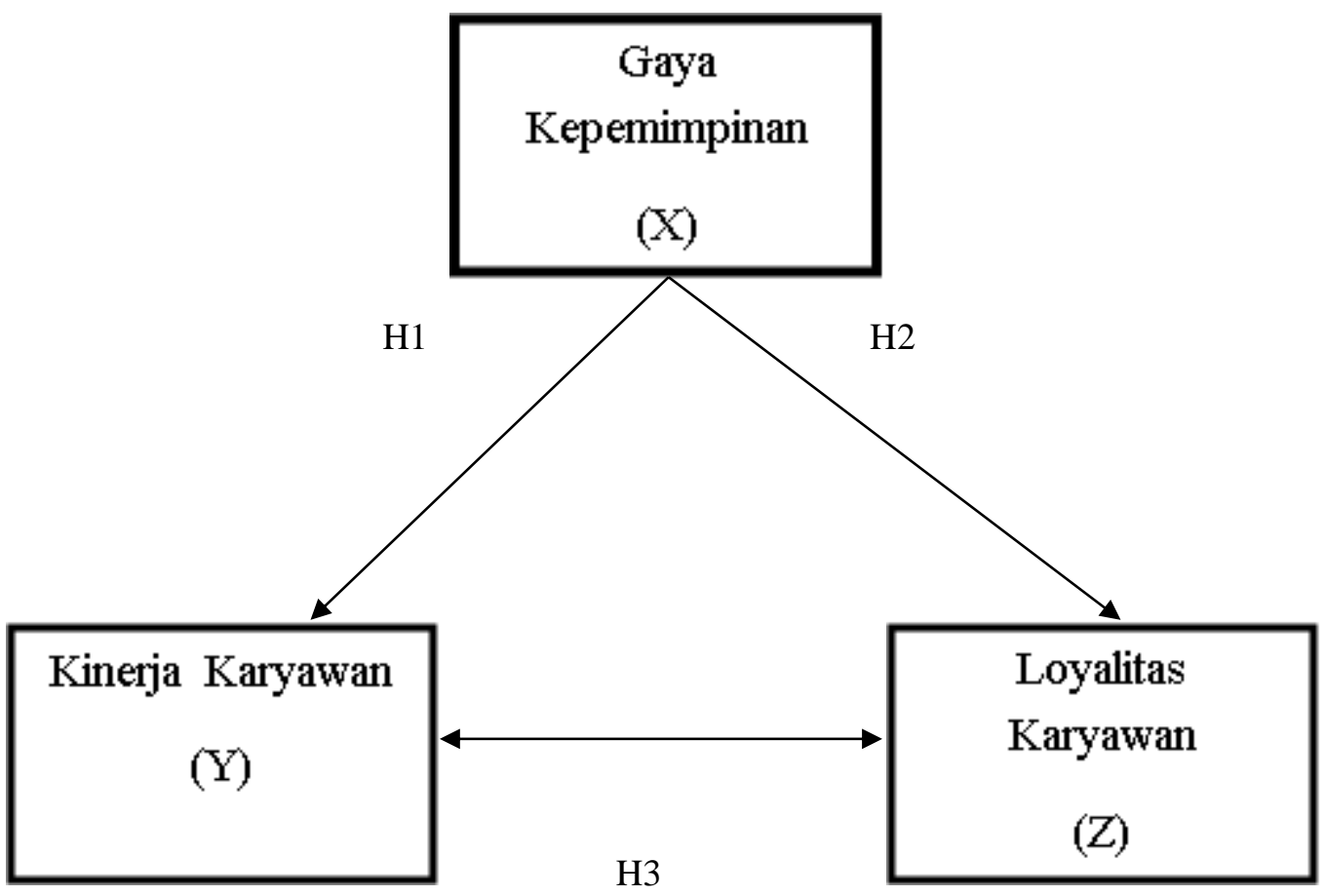

Gambar 1. Keragka Pikir

\section{Hipotesis}

$\mathrm{H} 1$ : (X) berpengaruh positif terhadap (Y)

Gaya Kepemimpinan berpengaruh positif terhadap Kinerja Karyawan 


\section{JURNAL EKOBIS: EKONOMI, BISNIS \& MANAJEMEN}

\section{Vol 9 Nomor 1 (2019)}

$\mathrm{H} 2$ : (X) berpengaruh positif terhadap (Z)

Gaya Kepemimpinan berpengaruh positif terhadap Loyalitas karyawan

$\mathrm{H} 3$ : (Y) berpengaruh positif terhadap (Z)

Kinerja Karyawan berpengaruh positif terhadap Loyalitas Karyawan

$\mathrm{H} 4$ : (X) berpengaruh positif terhadap (Y) melalui (Z)

Gaya Kepemimpinan berpengaruh positif terhadap Loyalitas Karyawan melalui

Kinerja Karyawan

\section{METODE PENELITIAN}

Objek yang dijadikan dalam penelitian ini adalah pada PT. Fastrata Buana Cabang Pulogadung dengan jumlah sample sebanyak 187 responden.

Berikut ini adalah variabel, indikator yang digunakan dalam penelitian ini :

Tabel 1. Operasional Variabel

\begin{tabular}{|c|c|c|c|c|}
\hline Variabel & Dimensi & Indikator & $\begin{array}{c}\text { Item } \\
\text { Pertanyaan }\end{array}$ & $\begin{array}{l}\text { Sumber } \\
\text { Referensi }\end{array}$ \\
\hline $\begin{array}{l}\text { Gaya Kepemimpinan } \\
\text { (X) adalah perilaku } \\
\text { yangdilakukan dan } \\
\text { ditunjukkan oleh } \\
\text { seorang pemimpin di } \\
\text { dalam memberikan } \\
\text { pengarahan terhadap } \\
\text { bawahannya dengan rasa } \\
\text { mempercayai bawahan } \\
\text { juga memuat bagaimana } \\
\text { cara bekerja sama } \\
\text { dengan bawahannya } \\
\text { dalam mengambil } \\
\text { keputusan, pembagian } \\
\text { tugas dan wewenang, } \\
\text { bagaimana cara } \\
\text { berkomunikasi dan } \\
\text { bagaimana hubungan } \\
\text { diantara pimpinan dan } \\
\text { bawahannya tersebut. }\end{array}$ & $\begin{array}{l}\text { X.1 Gaya } \\
\text { Kepemimpinan } \\
\text { Otokratis } \\
\text { X.2 Gaya } \\
\text { Kepemimpinan } \\
\text { Demokratis } \\
\\
\text { X.3. Gaya } \\
\text { Kepemimpinan } \\
\text { Otoriter } \\
\\
\text { X.4. Gaya } \\
\text { Kepemimpinan } \\
\text { Partisipatif } \\
\text { X.5. Gaya } \\
\text { Kepemimpinan } \\
\text { Delegatif }\end{array}$ & $\begin{array}{l}\text { X.1.1. Kekuatan } \\
\text { Posisi } \\
\text { X.1.2. Menggunakan } \\
\text { Otoritas } \\
\text { X.2.1. Kekuatan } \\
\text { personal } \\
\text { X.2.2. Memiliki jiwa } \\
\text { partisipasi } \\
\text { X.3.1. Kekuasaan } \\
\text { Dan wewenang } \\
\text { X.3.2. Tidak peduli } \\
\text { X.4.1. Motivasi } \\
\text { X.4.2. Membina Tim } \\
\text { Kerja } \\
\text { X.5.2. Keyakinan } \\
\text { Terhadap } \\
\text { Potensi } \\
\text { karyawan }\end{array}$ & $\begin{array}{l}\text { X.1.1 } \\
\text { X.1.2 } \\
\text { X.2.1 } \\
\text { X.2.2 } \\
\\
\text { X.3.1 } \\
\text { X.3.2 } \\
\text { X.4.1 } \\
\text { X.4.2 } \\
\text { X.5.1 }\end{array}$ & $\begin{array}{l}\text { Thoha (2013) } \\
\text { dan Hasibuan } \\
(2007)\end{array}$ \\
\hline $\begin{array}{l}\text { Kinerja Karyawan (Y) } \\
\text { adalah hasil pekerjaan } \\
\text { dalam jangka waktu } \\
\text { tertentu baik yang } \\
\text { berbentuk output } \\
\text { maupun input yang } \\
\text { dilakukan sesuai dengan }\end{array}$ & $\begin{array}{l}\text { Y.1. Efektivitas dan } \\
\text { Efisiensi } \\
\\
\begin{array}{l}\text { Y.2. Otoritas dan } \\
\text { Tanggung }\end{array}\end{array}$ & $\begin{array}{l}\text { Y.1.1. Tingkat } \\
\text { Efektivitas } \\
\text { Y.1.2. Tingkat } \\
\text { Efisiensi } \\
\\
\text { Y.2.1. Wewenang \& }\end{array}$ & $\begin{array}{l}\text { Y.1.1 } \\
\text { Y.1.2 } \\
\text { Y.2.1 } \\
\text { Y.2.2 }\end{array}$ & $\begin{array}{l}\text { Sutrisno } \\
(2011)\end{array}$ \\
\hline
\end{tabular}


JURNAL EKOBIS: EKONOMI, BISNIS \& MANAJEMEN

Vol 9 Nomor 1 (2019)

\begin{tabular}{|c|c|c|c|c|}
\hline $\begin{array}{l}\text { tanggung jawab individu } \\
\text { didasarkan dengan } \\
\text { kecakapan, kesungguhan } \\
\text { dan pengalaman serta } \\
\text { dapat mencapai target } \\
\text { sesuai hasil yang } \\
\text { diharapkan, tidak } \\
\text { melanggar hokum dan } \\
\text { sesuai dengan etika. }\end{array}$ & $\begin{array}{c}\text { Jawab } \\
\text { Y.3. Disiplin } \\
\text { Y.4. Inisiatif }\end{array}$ & $\begin{array}{l}\text { tanggung jawab } \\
\text { Y.2.2. Komitmen } \\
\text { Y.3.1. Peraturan dan } \\
\text { Ketepatan } \\
\text { perusahaan } \\
\text { Y.3.2. Ketaatan dan } \\
\text { hormat pada } \\
\text { perjanjian yang } \\
\text { dibuat } \\
\\
\text { Y.4.1. Daya Pikir } \\
\text { Y.4.2. Kreativitas }\end{array}$ & $\begin{array}{l}\text { Y.3.1 } \\
\text { Y.3.2 }\end{array}$ & \\
\hline $\begin{array}{l}\text { Loyalitas Karyawan }(\mathrm{Z}) \\
\text { adalah kemauan bekerja } \\
\text { sama yang berarti } \\
\text { kesediaan } \\
\text { mengorbankan } \\
\text { kepentingan pribadi, } \\
\text { kesediaan melakukan } \\
\text { pengawasan diri dan } \\
\text { kemauan untuk } \\
\text { menonjolkan diri sendiri }\end{array}$ & $\begin{array}{l}\text { Z.1. Taat pada } \\
\text { peraturan } \\
\begin{array}{l}\text { Z.2. Tanggung } \\
\text { jawab terhadap } \\
\text { perusahaan. }\end{array} \\
\text { Z.3. Kemauan untuk } \\
\text { bekerja sama. } \\
\text { Z.4. Rasa memiliki. } \\
\text { Z.6. Suka terhadap } \\
\text { perusahaan. }\end{array}$ & 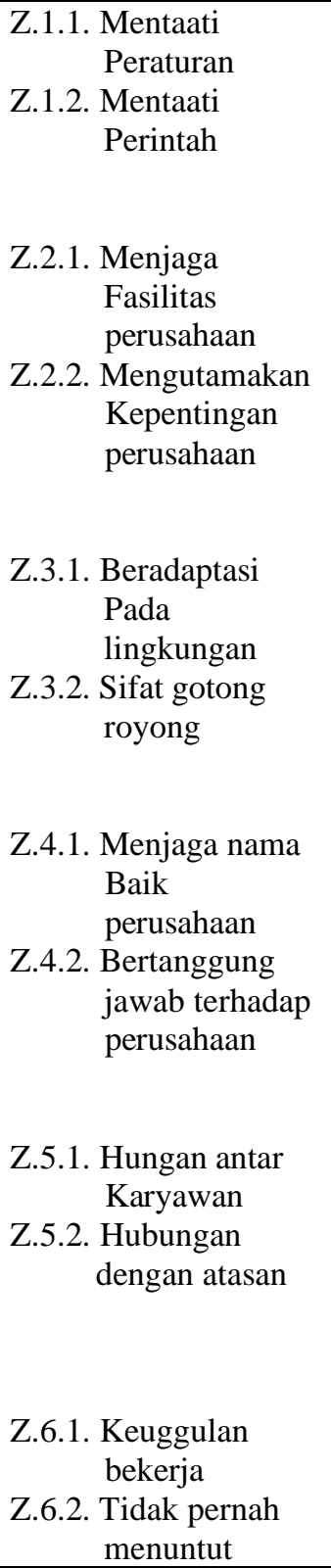 & $\begin{array}{l}\text { Z.1.1 } \\
\text { Z.1.2 } \\
\text { Z.2.1 } \\
\text { Z.2.2 } \\
\text { Z.3.1 } \\
\text { Z..3.2 } \\
\text { Z.4.1 } \\
\text { Z.5.6. } \\
\text { Z.4.2 } \\
\end{array}$ & $\begin{array}{l}\text { Siswanto } \\
(2005)\end{array}$ \\
\hline
\end{tabular}

Sumber : Data diolah 
Adapun model dari penelitian ini adalah :

$$
\begin{aligned}
& Y=\alpha+B x+e_{1} \\
& Z=\alpha+\beta_{1} X+\beta_{2} Z+\beta_{3} X Z+e_{2} \\
& \text { Dimana: } \\
& Y=\text { Kinerja Karyawan } \\
& Z=\text { Loyalitas Karyawan } \\
& \alpha=\text { Alpha } \\
& \beta=\text { Beta } \\
& e=\text { Error }
\end{aligned}
$$

\section{PEMBAHASAN}

\section{Analisis Deskripsi}

\begin{tabular}{|c|c|c|c|c|c|c|c|c|c|c|c|}
\hline \multirow{2}{*}{ Variabel Indokator } & \multicolumn{2}{|c|}{1} & \multicolumn{2}{|c|}{2} & \multicolumn{2}{|r|}{3} & \multicolumn{2}{|c|}{4} & \multicolumn{2}{|c|}{5} & \multirow{2}{*}{ MEAN } \\
\hline & $\mathrm{F}$ & $\%$ & $\mathrm{~F}$ & $\%$ & $\mathrm{~F}$ & $\%$ & $\mathrm{~F}$ & $\%$ & $\mathrm{~F}$ & $\%$ & \\
\hline Gaya Kepemimpinan & & & & & & & & & & & 3.79 \\
\hline X.1.1 & 0 & $0 \%$ & 0 & $0 \%$ & 5 & $4 \%$ & 53 & $41 \%$ & 72 & $55 \%$ & 4.51 \\
\hline X.1.2 & 56 & $43 \%$ & 41 & $32 \%$ & 10 & $8 \%$ & 22 & $17 \%$ & 1 & $1 \%$ & 2.00 \\
\hline X.2.1 & 0 & $0 \%$ & 0 & $0 \%$ & 1 & $1 \%$ & 47 & $36 \%$ & 82 & $63 \%$ & 4.62 \\
\hline X.2.2 & 0 & $0 \%$ & 1 & $1 \%$ & 14 & $11 \%$ & 105 & $81 \%$ & 10 & $8 \%$ & 3.95 \\
\hline X.3.1 & 0 & $0 \%$ & 0 & $0 \%$ & 19 & $15 \%$ & 56 & $43 \%$ & 55 & $42 \%$ & 4.28 \\
\hline X.3.2 & 56 & $43 \%$ & 41 & $32 \%$ & 22 & $17 \%$ & 8 & $6 \%$ & 3 & $2 \%$ & 1.93 \\
\hline X.4.1 & 0 & $0 \%$ & 0 & $0 \%$ & 0 & $0 \%$ & 73 & $56 \%$ & 57 & $44 \%$ & 4.44 \\
\hline X.4.2 & 0 & $0 \%$ & 0 & $0 \%$ & 4 & $3 \%$ & 81 & $62 \%$ & 45 & $35 \%$ & 4.32 \\
\hline X.5.1 & 0 & $0 \%$ & 4 & $3 \%$ & 24 & $18 \%$ & 98 & $75 \%$ & 4 & $3 \%$ & 3.79 \\
\hline X.5.2 & 0 & $0 \%$ & 0 & $0 \%$ & 1 & $1 \%$ & 119 & $92 \%$ & 10 & $8 \%$ & 4.07 \\
\hline Kinerja Karyawan & & & & & & & & & & & 4.50 \\
\hline Y.1.1 & 0 & $0 \%$ & 0 & $0 \%$ & 1 & $1 \%$ & 34 & $26 \%$ & 95 & $73 \%$ & 4.72 \\
\hline Y.1.2 & 0 & $0 \%$ & 1 & $1 \%$ & 1 & $1 \%$ & 70 & $54 \%$ & 58 & $45 \%$ & 4.42 \\
\hline Y.2.1 & 0 & $0 \%$ & 0 & $0 \%$ & 1 & $1 \%$ & 35 & $27 \%$ & 94 & $72 \%$ & 4.72 \\
\hline Y.2.2 & 0 & $0 \%$ & 0 & $0 \%$ & 1 & $1 \%$ & 40 & $31 \%$ & 89 & $68 \%$ & 4.68 \\
\hline Y.3.1 & 0 & $0 \%$ & 0 & $0 \%$ & 2 & $2 \%$ & 38 & $29 \%$ & 90 & $69 \%$ & 4.68 \\
\hline Y.3.2 & 0 & $0 \%$ & 0 & $0 \%$ & 5 & $4 \%$ & 78 & $60 \%$ & 47 & $36 \%$ & 4.32 \\
\hline Y.4.1 & 0 & $0 \%$ & 0 & $0 \%$ & 5 & $4 \%$ & 91 & $70 \%$ & 34 & $26 \%$ & 4.22 \\
\hline Y.4.2 & 0 & $0 \%$ & 0 & $0 \%$ & 3 & $2 \%$ & 92 & $71 \%$ & 35 & $27 \%$ & 4.25 \\
\hline Loyalitas Karyawan & & & & & & & & & & & 4.38 \\
\hline Z.1.1 & 0 & $0 \%$ & 0 & $0 \%$ & 1 & $1 \%$ & 30 & $23 \%$ & 99 & $76 \%$ & 4.75 \\
\hline Z.1.2 & 0 & $0 \%$ & 0 & $0 \%$ & 2 & $2 \%$ & 74 & $57 \%$ & 54 & $42 \%$ & 4.4 \\
\hline Z.2.1 & 0 & $0 \%$ & 0 & $0 \%$ & 1 & $1 \%$ & 79 & $61 \%$ & 50 & $38 \%$ & 4.38 \\
\hline Z.2.2 & 5 & $4 \%$ & 15 & $12 \%$ & 44 & $34 \%$ & 58 & $45 \%$ & 8 & $6 \%$ & 3.38 \\
\hline
\end{tabular}

Pada tahapan ini akan dilakukan análisis terhadap variabel-variabel penelitian berdasarkan ítem pertanyaan dalam kuisioner. Variabel Gaya Kepemimpinan terdiri dari 10 indikator pertanyaan yaitu X.01 - X.10, variabel Kinerja Karyawan terdiri dari 8 indikator pertanyaan yaitu Y.01 - Y.08, dan variabel Loyalitas Karyawan terdiri dari 12 indikator pertanyaan yaitu Z.01 - Z.12. Deskripsi dari variabel-variabel penelitian tersebut dijelaskan pada tabel 4.5 sebagai berikut :

Tabel 2. Deskripsi penelitian 
JURNAL EKOBIS: EKONOMI, BISNIS \& MANAJEMEN

Vol 9 Nomor 1 (2019)

\begin{tabular}{|c|c|c|c|c|c|c|c|c|c|c|c|}
\hline \hline Z.3.1 & 0 & $0 \%$ & 0 & $0 \%$ & 1 & $1 \%$ & 51 & $39 \%$ & 78 & $60 \%$ & 4.59 \\
\hline Z..3.2 & 0 & $0 \%$ & 0 & $0 \%$ & 9 & $7 \%$ & 56 & $43 \%$ & 65 & $50 \%$ & 4.43 \\
\hline Z.4.1 & 0 & $0 \%$ & 0 & $0 \%$ & 0 & $0 \%$ & 82 & $63 \%$ & 48 & $37 \%$ & 4.38 \\
\hline Z.4.2 & 0 & $0 \%$ & 0 & $0 \%$ & 21 & $16 \%$ & 105 & $81 \%$ & 4 & $3 \%$ & 3.87 \\
\hline Z.5.1 & 0 & $0 \%$ & 0 & $0 \%$ & 0 & $0 \%$ & 24 & $18 \%$ & 106 & $82 \%$ & 4.82 \\
\hline Z.5.2 & 0 & $0 \%$ & 0 & $0 \%$ & 0 & $0 \%$ & 25 & $19 \%$ & 105 & $81 \%$ & 4.81 \\
\hline Z.6.1 & 0 & $0 \%$ & 1 & $1 \%$ & 2 & $2 \%$ & 57 & $44 \%$ & 70 & $54 \%$ & 4.51 \\
\hline Z.6.2 & 0 & $0 \%$ & 1 & $1 \%$ & 10 & $8 \%$ & 75 & $58 \%$ & 44 & $34 \%$ & 4.25 \\
\hline
\end{tabular}

Sumber : Data Primer diolah, 2017

Berdasarkan tabel diatas indikator-indikator variabel Gaya Kepemimpinan memiliki means sebesar 3.79 yang berarti memiliki kecenderungan respon positif. Artinya dalam hal ini responden yang merupakan karyawan PT. Fastrata Buana cabang Pulogadung merasa bahwa sistem Gaya Kepemimpinan diperusahaan cukup sesuai dengan harapan para karyawan.

Variabel yang kedua yaitu Kinerja Karyawan, dimana meansnya sebesar 4.50 yang berarti masih memiliki kecenderungan positif. Artinya bahwa karyawan PT. Fastrata buana memiliki cara kerja yang baik dan tepat waktu.

Variabel yang ketiga yaitu Loyalitas Karyawan, dimana memiliki means sebesar 4.38 yang berarti memiliki kecenderungan positif. Artinya bahwa para karyawan PT. Fastrata buana memiliki rasa loyalitas yang tinggi terhadap perusahaan.

\section{Uji Validitas}

Sebelum dilakukan análisis model jalur dan hipótesis, dilakukan pengujian validitas dan reliabilitas pada masing-masing indikator pertanyaan dengan menggunakan bantuan software Smart PLS 3.0. Ukuran refleksif individual dikatakan valid jika memiliki nilai loading (a) dengan variable laten yang ingin diukur $\geq 0.5$, jika salah satu indikator memiliki nilai loading (a) $<0.5$ maka indikator tersebut harus dibuang (di drop) karena mengindikasikan bahwa indikator tidak cukup baik untuk mengukur variable laten secara tepat. Konstruk laten Gaya Kepemimpinan diukur oleh indikator X.1.1 - X.5.2, variabel Kinerja Karyawan diukur oleh indikator Y.1.1 - Y.4.2, variabel Loyalitas Karyawan diukur oleh indokator Z.1.1 - Z.6.2. Berikut ini adalah hasil output factor loading variabel penelitian pada Smart PLS : 


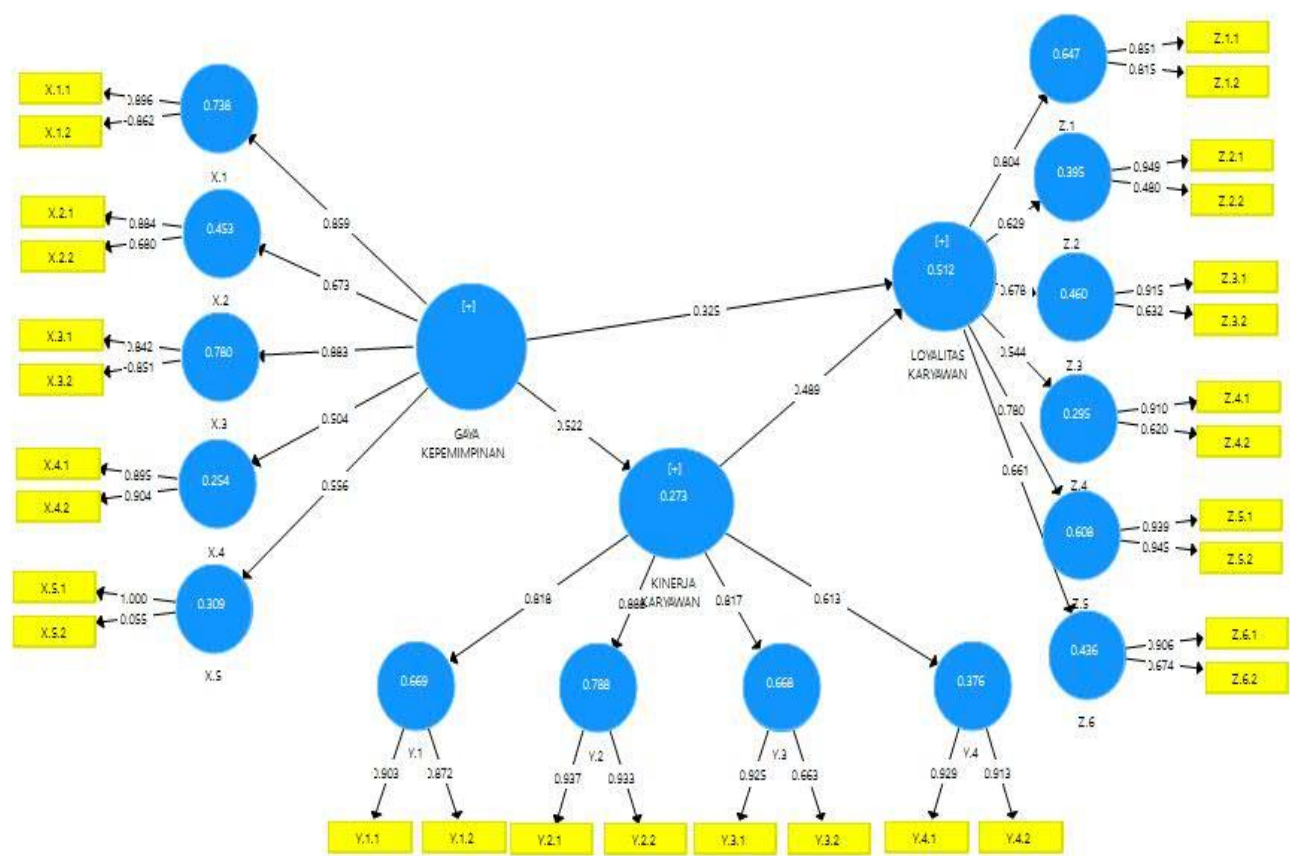

Gambar 2 : Loading Factor variabel penelitian Sumber : hasil diolah smart PLS

Berdasarkan nilai factor loading di atas, masih terdapat faktor loading yang nilainya di bawah 0.5 . Tabel 3 berikut ini mendeskripsikan faktor loading dan nilai $\mathrm{T}_{\text {statistik }}$ untuk masing-masing indikator :

Tabel 3

Tabel Factor Loading dan Nilai Statistik 
JURNAL EKOBIS: EKONOMI, BISNIS \& MANAJEMEN

Vol 9 Nomor 1 (2019)

\begin{tabular}{|c|c|c|c|c|c|c|}
\hline \multirow[b]{2}{*}{ Variabel } & \multirow[b]{2}{*}{ Indikator } & \multirow[b]{2}{*}{ Loading } & \multicolumn{3}{|c|}{ T-Statistik } & \multirow[b]{2}{*}{ Keterangan } \\
\hline & & & $\begin{array}{c}\text { Gaya } \\
\text { Kepemim } \\
\text { pinan }(X)\end{array}$ & $\begin{array}{c}\text { Kinerja } \\
\text { Karyaw } \\
\text { an }(\mathrm{Y})\end{array}$ & $\begin{array}{l}\text { Loyalita } \\
\text { s } \\
\text { Karyaw } \\
\text { an (Z) }\end{array}$ & \\
\hline \multirow{10}{*}{$\begin{array}{l}\text { Gaya } \\
\text { Kepemimpin } \\
\text { an }(X)\end{array}$} & X.1.1 & 0.896 & 61.053 & & & Valid dan Signifikan \\
\hline & X.1.2 & -0.862 & 34.789 & & & $\begin{array}{c}\text { Tidak Valid dan } \\
\text { Signifikan } \\
\end{array}$ \\
\hline & X.2.1 & 0.884 & 20.876 & & & Valid dan Signifikan \\
\hline & X.2.2 & 0.680 & 6.197 & & & Valid dan Signifikan \\
\hline & X.3.1 & 0.842 & 27.046 & & & Valid dan Signifikan \\
\hline & X.3.2 & -0.851 & 27.147 & & & $\begin{array}{l}\text { Tidak Valid dan } \\
\text { Signifikan }\end{array}$ \\
\hline & X.4.1 & 0.895 & 30.149 & & & Valid dan Signifikan \\
\hline & X.4.2 & 0.904 & 24.657 & & & Valid dan Signifikan \\
\hline & X.5.1 & 1.000 & 27.081 & & & Valid dan Signifikan \\
\hline & X.5.2 & 0.055 & 0.310 & & & $\begin{array}{l}\text { Tidak Valid dan } \\
\text { Signifikan }\end{array}$ \\
\hline \multirow{8}{*}{$\begin{array}{l}\text { Kinerja } \\
\text { Karyawan } \\
(\mathrm{Y})\end{array}$} & Y.1.1 & 0.903 & & 71.062 & & Valid dan Signifikan \\
\hline & Y.1.2 & 0.872 & & 41.770 & & Valid dan Signifikan \\
\hline & Y.2.1 & 0.937 & & 60.615 & & Valid dan Signifikan \\
\hline & Y.2.2 & 0.933 & & 52.464 & & Valid dan Signifikan \\
\hline & Y.3.1 & 0.925 & & 48.271 & & Valid dan Signifikan \\
\hline & Y.3.2 & 0.663 & & 5.806 & & Valid dan Signifikan \\
\hline & Y.4.1 & 0.929 & & 56.996 & & Valid dan Signifikan \\
\hline & Y.4.2 & 0.913 & & 35.592 & & Valid dan Signifikan \\
\hline \multirow{12}{*}{$\begin{array}{l}\text { Loyalitas } \\
\text { Karyawan } \\
\text { (Z) }\end{array}$} & Z.1.1 & 0.851 & & & 29.307 & Valid dan Signifikan \\
\hline & Z.1.2 & 0.815 & & & 27.900 & Valid dan Signifikan \\
\hline & Z.2.1 & 0.949 & & & 27.378 & Valid dan Signifikan \\
\hline & Z.2.2 & 0.480 & & & 2.700 & $\begin{array}{l}\text { Tidak Valid dan } \\
\text { Signifikan }\end{array}$ \\
\hline & Z.3.1 & 0.915 & & & 24.978 & Valid dan Signifikan \\
\hline & Z.3.2 & 0.632 & & & 4.475 & Valid dan Signifikan \\
\hline & Z.4.1 & 0.910 & & & 16.361 & Valid dan Signifikan \\
\hline & Z.4.2 & 0.620 & & & 3.122 & Valid dan Signifikan \\
\hline & Z.5.1 & 0.939 & & & 42.472 & Valid dan Signifikan \\
\hline & Z.5.2 & 0.945 & & & 52.123 & Valid dan Signifikan \\
\hline & Z.6.1 & 0.906 & & & 29.005 & Valid dan Signifikan \\
\hline & Z.6.2 & 0.674 & & & 6.134 & Valid dan Signifikan \\
\hline
\end{tabular}

Sumber : Hasil diolah Smart PLS 3.0

Karena memiliki nilai convergent validity yang rendah, maka indikator-indikator yang memiliki loading factor di bawah 0,5 tersebut harus di drop. Berdasarkan output diatas indikator X.1.2, X.3.2, X.5.2, dan Z.2.2 loadingnya masih dibawah 0,5 sehingga indikator-indikator tersebut harus di drop.

Setelah indikator-indikator tersebut di drop, maka dilakukan analisis kembali. Berikut ini adalah hasil output diagram jalur persamaan structural yang sudah diperbaiki : 
Berdasarkan output pada diagram jalur diatas, factor loading untuk Second Order sudah memenuhi convergent validity yaitu nilai indikatornya sudah diatas 0.5 .

\section{Uji Realibilitas}

Dalam penelitian, suatu variabel dikatakan cukup reliabilitas bila variabel tersebut mempunyai nilai construct reability lebih besar dari 0,6 . Berikut ini adalah tabel hasil pengujian reliabilitas pada masing-masing variabel penelitian.

Tabel 5. Uji Reliabilitas

\begin{tabular}{|c|c|}
\hline Variabel & $\begin{array}{l}\text { Composite } \\
\text { Reliability }\end{array}$ \\
\hline Gaya Kepemimpinan (X) & 0.537 \\
\hline Kinerja Karyawan (Y) & 0.880 \\
\hline Loyalitas Karyawan (Z) & 0.837 \\
\hline
\end{tabular}

Sumber : Hasil diolah Smart PLS 3.0

Berdasarkan hasil output reliabilitas diatas, dapat disimpulkan bahwa untuk semua dimensi dalam variable kinerja karyawan dan loyalitas karyawan memiliki composite reliability diatas 0.6 , kecuali gaya kepemimpinan yang memiliki nilai composite reliability hanya 0.537 (dibawah 0.6) tetapi variabel tersebut masih bisa diterima karena masing-masing sub marginal dan indikator-indikatornya valid dan signifikan, sehingga dapat disimpulkan bahwa indikator-indikator yang digunakan pada masing-masing dimensi mempunyai reliabilitas yang cukup baik atau mampu untuk mengukur konstruknya.

\section{Evaluasi Goodness Of Fit Model Structural (Inner Model)}

Evaluasi goodness of fit model structural diukur dengan menggunakan nilai predictive-relevamce $\left(\mathrm{Q}^{2}\right)$. Nilai oredictive-relevance $\left(\mathrm{Q}^{2}\right)$ dihitung dengan menggunakan rumus sebagai berikut :

$$
\mathrm{Q}^{2}=1-\left(1-\mathrm{R}^{21}\right)\left(1-\mathrm{R}^{22}\right) \ldots \mathrm{n}
$$

\section{Koefisien Determinasi}

Koefisien Determinasi $\left(\mathrm{R}^{2}\right)$ merupakan bagian dari variasi total dalam variabel dependen yang dijelaskan oleh variasi dalam variabel dependen. Tabel 4.9 berikut ini menjelaskan hasil analisis koefisien determinasi dari variabel-variabel penelitian : 
Tabel 6. R Square

\begin{tabular}{|c|c|}
\hline Variabel & R Square \\
\hline Kinerja Karyawan $(\mathrm{Y})$ & 0.274 \\
\hline Loyalitas Karyawn $(\mathrm{Z})$ & 0.511 \\
\hline Predictive-Relevance $\left(\mathrm{Q}^{2}\right)$ & 0.645 \\
\hline
\end{tabular}

Berdasarkan koefisien determinasi pada table diatas, diperoleh nilai $\mathrm{R}^{2}$ untuk variabel Kinerja Karyawan sebesar 0.274 yang artinya nilai tersebut mengindikasikan bahwa variabel Kinerja Karyawan dapat dijelaskan oleh variabel Gaya Kepemimpinan sebesar 27.4\% sedangkan sisanya yaitu sebesar $72.6 \%$ dipengaruhi oleh variabel lain yang tidak terdapat dalam model penelitian. Nilai $\mathrm{R}^{2}$ untuk variabel Loyalitas Karyawan sebesar 0.511 yang artinya bahwa variabel Loyalitas Karyawan dijelaskan oleh variabel Gaya Kepemimpinan sebesar 51.1\% sedangkan sisanya yaitu sebesar $48.9 \%$ dipengaruhi oleh variabel lain yang tidak terdapat dalam model penelitian. Evaluasi inner model yang pertama dan kedua cukup baik dalam menjelaskan variabel Kinerja Karyawan dan Loyalitas Karyawan, sedangkan nilai predictive- relevance untuk model struktural dalam penelitian ini adalah sebesar 0.645 atau $64.5 \%$, artinya model tersebut mampu menjelaskan fenomena Loyalitas Karyawan dikaitkan dengan beberapa variabel yaitu Gaya Kepemimpinan dan Kinerja Karyawan. Oleh karena itu model dapat dikatakan baik, atau model memiliki nilai prediktif yang baik. Pada akhirnya model dapat digunakan untuk menguji hipotesis.

\section{Pengujian hipotesis}

Untuk menguji hipotesis dalam penelitian ini, digunakan nilai $\mathrm{T}_{\text {statistik }}$ pada masing-masing jalur pengaruh langsung secara parsial. Berikut ini adalah gambar yang menjelaskan diagram jalur untuk pengujian hipotesis : 


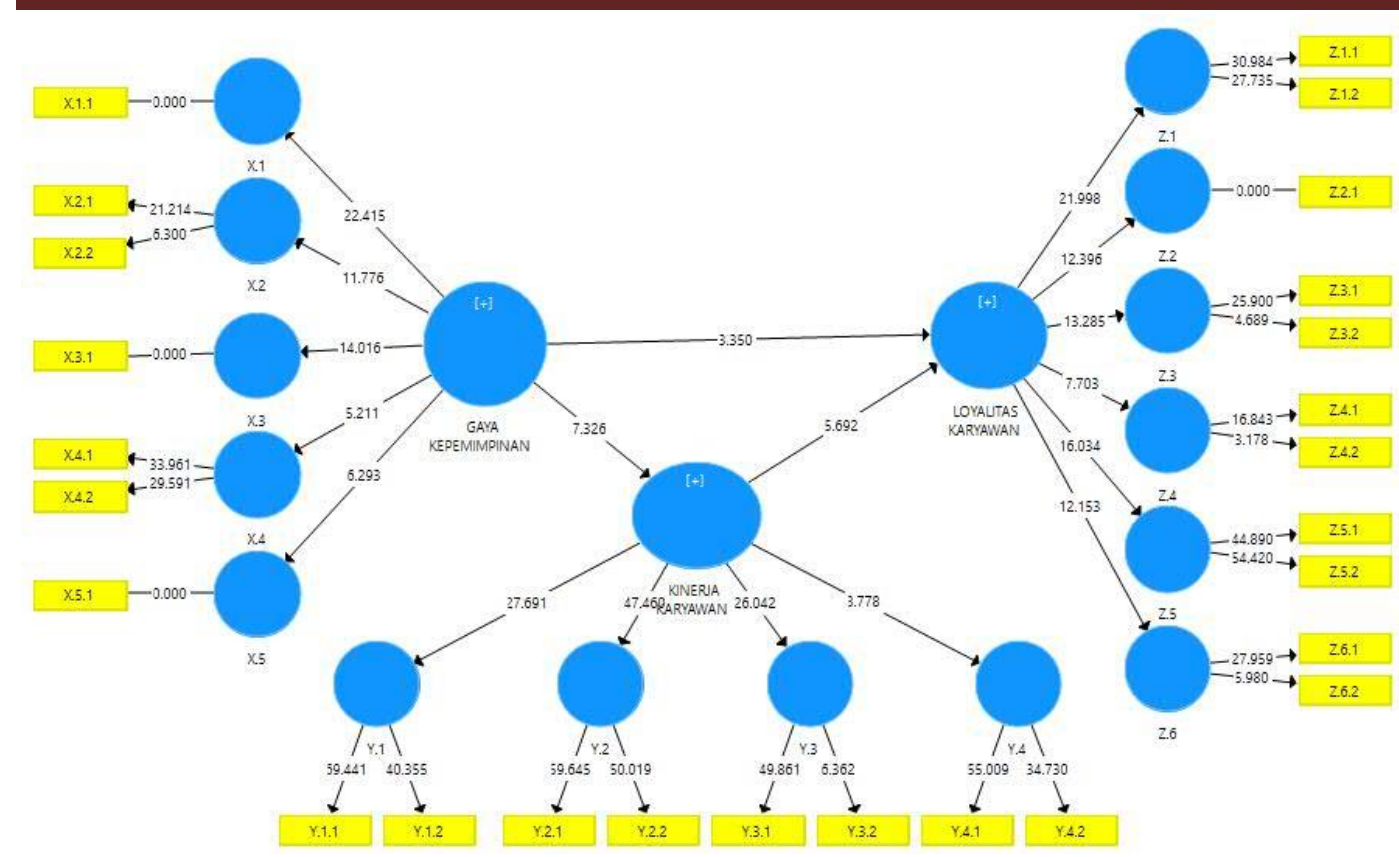

Gambar 3. Output Diagram Path penguji hipotesis Sumber : Hasil diolah Smart PLS 3.0

Berdasarkan diagram path pengujian hipotesis diatas, semua dimensi pada masingmasing variabel mempunyai nilai $\mathrm{T}_{\text {statistik }}$ lebih dari $1.660\left(\mathrm{t}_{\text {tabel }}\right)$ sehingga dimensi-dimensi tersebut mampu mengukur setiap konstruknya. Sedangkan untuk menguji hubungan antar variabel (uji hipotesis), maka digunakan nilai $\mathrm{T}_{\text {statistik }}$ dari output Smart PLS yang dibandingkan dengan nilai $t_{\text {tabel. }}$. Berikut ini adalah tabel yang memberikan hasil hubungan antar konstruk (variabel).

Tabel 7. Pengujian Hipotesis

\begin{tabular}{|l|c|c|c|c|}
\hline Hubungan Antar Variabel & $\begin{array}{c}\text { Koefisien } \\
\text { Parameter }\end{array}$ & Standar Eror & T Statistik & Keterangan \\
\hline $\begin{array}{l}\text { Gaya Kepemimpinan -> } \\
\text { Kinerja Karyawan }\end{array}$ & 0.542 & 0.071 & 7.326 & Signifikan \\
\hline $\begin{array}{l}\text { Gaya Kepemimpinan -> } \\
\text { Loyalitas Karyawan }\end{array}$ & 0.324 & 0.097 & 3.350 & Signifikan \\
\hline $\begin{array}{l}\text { Kinerja Karyawan -> } \\
\text { Loyalitas Karyawan }\end{array}$ & 0.490 & 0.086 & 5.692 & Signifikan \\
\hline $\begin{array}{l}\text { Gaya Kepemimpinan -> } \\
\text { Loyalitas Karyawan -> } \\
\text { Kinerja Karyawan }\end{array}$ & 0.257 & 0.064 & 4.009 & Signifikan \\
\hline
\end{tabular}

Sumber : Hasil diolah Smart PLS 3.0 


\section{JURNAL EKOBIS: EKONOMI, BISNIS \& MANAJEMEN} Vol 9 Nomor 1 (2019)

Pengaruh hubungan variabel laten eksogen terhadap variabel laten endogen pada tabel diatas dapat dijelaskan sebagai berikut :

Koefisien parameter jalur yang diperoleh dari pengaruh variabel Gaya Kepemimpinan terhadap Kinerja Karyawan adalah sebesar 0.542 dengan nilai $t_{\text {statistik }} 7.326>1.660$ pada taraf signifikansi $\alpha=0,05(5 \%)$ yang menyatakan bahwa terdapat pengaruh positif dan signifikan antara Gaya Kepemimpinan terhadap Kinerja Karyawan. Nilai 0.542 pada koefisien parameter artinya adalah semakin baik Gaya Kepemimpinan maka Kinerja Karyawan akan semakin baik, dan ini mendukung hipotesis penelitian yang pertama, dimana terdapat pengaruh positif dan signifikan antara Gaya Kepemimpinan terhadap Kinerja Karyawan.

Koefisien parameter jalur yang diperoleh dari pengaruh variable Gaya Kepemimpinan terhadap Loyalitas Karyawan adalah sebesar 0.324 dengan nilai tstatistik $3.350>1.660$ pada taraf signifikan $\alpha=0,05$ (5\%) yang menyatakan bahwa terdapat pengaruh positif dan signifikan antara kompensasi terhadap Loyalitas Karyawan. Nilai 0.324 pada koefisien parameter artinya adalah semakin baik Gaya Kepemimpinan maka Loyalitas Karyawan akan semakin baik, dan ini mendukung hipotesis penelitian yang kedua, dimana terdapat pengaruh positif dan signifikan antara Gaya Kepemimpinan terhadap Loyalitas Karyawan.

Koefisien parameter jalur yang diperoleh dari pengaruh variable Kinerja Karyawan terhadap Loyalitas Karyawan adalah sebesar 0.490 dengan nilai tstatistik $5.692>1.660$ pada taraf signifikansi $\alpha=0,05(5 \%)$ yang menyatakan bahwa terdapat pengaruh positif dan signifikan antara Kinerja Karyawan terhadap Loyalitas Karyawan. Nilai 0.490 pada koefisien parameter artinya adalah semakin baik Kinerja Karyawan maka Loyalitas Karyawan juga akan semakin baik, dan ini mendukung hipotesis penelitian yang ketiga, dimana terdapat pengaruh positif dan signifikan antara Kinerja Karyawan terhadap Loyalitas Karyawan.

Koefisien parameter jalur yang diperoleh dari variabel tidak langsung yaitu Gaya Kepemimpinan terhadap Loyaitas Karyawan melalui Kinerja Karyawan adalah sebesar 0.257 dengan nilai tstatistik $4.009>1.660$ pada taraf signifikan $\alpha=0,05(5 \%)$ yang menyatakan bahwa terdapat pengaruh positif dan signifikan antara Gaya Kepemimpinan terhadap Loyalitas Karyawan melalu Kinerja Karyawan. Nilai 0.257 pada koefisien parameter artinya adalah semakin baik gaya kepemimpinan maka loyalitas karyawan melalui kinerja karyawan akan semakin baik pula, dan ini mendukung hipotesis penelitian yang keempat, dimana terdapat pengaruh positif dan signifikan antara Gaya Kepemimpinan terhadap Loyalitas Karyawan melalui Kinerja Karyawan.

Berdasarkan koefisien-koefisien parameter jalur yang diperoleh pada tabel 4.8 dan penjelasan diatas, maka model persamaan penelitian yang terbentuk dapat dijelaskan dalam gambar seperti model yang diajukan dalam penelitiam ini : 


\section{JURNAL EKOBIS: EKONOMI, BISNIS \& MANAJEMEN}

Vol 9 Nomor 1 (2019)

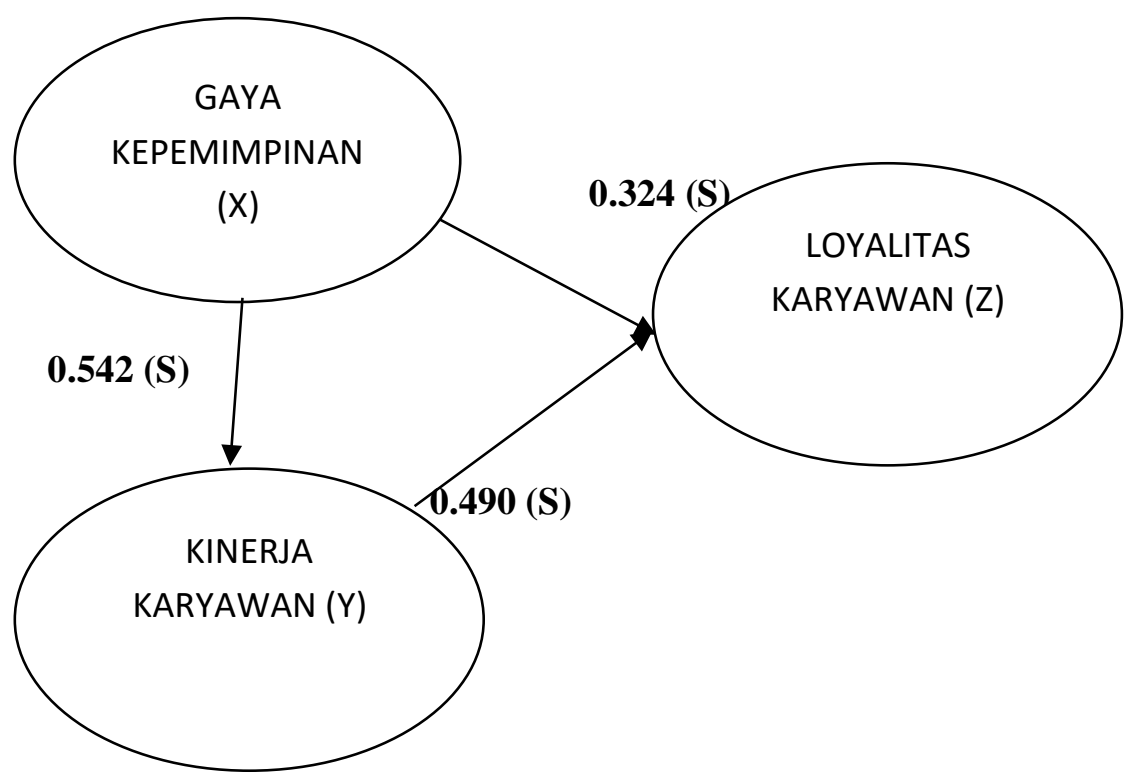

Gambar 4. Model Diagram Jalur Penelitian

Sumber : Hasil diolah Smart PLS 3.0

Berdasarkan diagram jalur penelitian diatas, kemudian diterjemahkan ke dalam bentuk persamaan sebagai berikut :

$$
\begin{aligned}
& \mathrm{KK}=0.542 \mathrm{GK}+\mathrm{e}_{1} \\
& \mathrm{LK}=0.324 \mathrm{GK}+0.490 \mathrm{KK}+\mathrm{e}_{2} \\
& \text { Keterangan : } \\
& \mathrm{LK} \quad \text { : Loyalitas Karyawan } \\
& \mathrm{GK} \quad \text { : Gaya Kepemimpinan } \\
& \mathrm{KK} \quad \text { : Kinerja Karyawan } \\
& \mathrm{e}: \text { Error }
\end{aligned}
$$

Pada model penelitian, pengaruh gaya kepemimpinan terhadap kinerja karyawan memiliki nilai koefisien yang lebih besar dibandingkan dengan nilai koefisien parameter loyalitas karyawan. Artinya gaya kepemimpinan lebih berpengaruh terhadap kinerja karyawan dibandingan loyalitas karyawan.

\section{PEMBAHASAN}

Penelitian mengenai pengaruh Gaya Kepemimpinan terhadap Kinerja Karyawan dan dampaknya terhadap Loyalitas Karyawan PT. Fastrata Buana Cabang Pulogadung dibuat pembahasan sebagai berikut :

\section{Pengaruh Gaya Kepemimpinan terhadap Kinerja Karyawan}

Berdasarkan hasil analisa menunjukkan, bahwa terdapat pengaruh positif dan signifikan antara Gaya Kepemimpinan terhadap Kinerja Karyawan. Hasil ini menunjukkan bahwa dengan kebijakan Gaya Kepemimpinan yang tepat maka Kinerja Karyawan akan meningkat. Hal ini sejalan dengan penelitian yang dilakukan oleh Emilia Ika Andriyani (2016) yang menjelaskan bahwa gaya kepemimpinan berpengaruh positif terhadap kinerja karyawan. Gaya kepemimpinan mengandung sifat yang professional dimana dengan adanya sikap pemimpin yang perhatian, ramah dan selalu memberikan motivasi kepada karyawan akan membuat karyawan merasa diperhatikan dan diberikan motivasi dalam mengerjakan pekerjaannya. 


\section{JURNAL EKOBIS: EKONOMI, BISNIS \& MANAJEMEN} Vol 9 Nomor 1 (2019)

\section{Pengaruh Gaya Kepemimpinan terhadap Loyalitas Karyawan}

Berdasarkan hasil analisa menunjukkan, Gaya Kepemimpinan berpengaruh positif dan signifikan terhadap Loyalitas Karyawan. Hasil ini menunjukkan bahwa dengan kebijakan Gaya Kepemimpinan yang tepat dan dapat diterima oleh karyawan maka akan meningkat Loyalitas Karyawan PT. Fastrata Buana Cabang Pulogadung. Dengan adanya sikap Gaya Kepemimpinan yang tepat dapat menumbuhkan sifat kecintaan karyawan baik terhadap pekerjaan maupun terhadap perusahaan.

\section{Pengaruh Kinerja Karyawan terhadap Loyalitas Karyawan}

Berdasarkan hasil penelitian yang dilakukan, bahwa terdapat pengaruh positif dan signifikan antara Kinerja Karyawan terhadap Loyalitas Karyawan. Artinya adalah semakin baik Kinerja Karyawan maka Loyalitas Karyawan juga akan semakin baik. Loyalitas Karyawan yang tinggi akan menguntungkan perusahaan karena dengan adanya loyalitas karyawan yang tinggi dapat menciptakan rasa kecintaan karyawan terhadap pekerjaan dan perusahaan, sehingga karyawan dapat bekerja dengan baik dan optimal dan apa yang dikerjakan oleh karyawan dapat mencapai tujuan perusahaan.

\section{Pengaruh Gaya Kepemimpinan terhadap Loyalitas Karyawan melalui Kinerja Karyawan}

Berdasarkan hasil penelitian yang dilakukan, bahwa terdapat pengaruh positif dan signifikan antara gaya kepemimpinan terhadap loyalitas karyawan melalui kinerja karyawan.

\section{PENUTUP}

Kesimpulan

Berdasarkan penelitian baik melalui analisis persepsi maupun analisis empires, PT. Fastrata Buana Cabang Pulogadung dalam melaksanakan sistem gaya kepemimpinan masih belum sesuai dengan harapan karyawan. Ada beberapa hal ketidaksesuaian yang masih dilakukan pemimpin terhadap karyawan, misalnya kurangnya rasa peduli pemimpinan terhadap kebutuhan karyawan untuk menyelesaikan pekerjaan, serta kurangnya perhatian pemimpin dalam memberikan motivasi kepada karyawan, sehingga karyawan kurang semangat dalam menyelesaikan pekerjaannya. Selain itu adanya sikap otoriter atasan terhadap bawahan sehingga bawahan menjadi kurang terbuka kepada atasan jika sedang menghadapi masalah dalam menyelesaikan masalah pekerjaan. Secara empires, gaya kepemimpinan berpengaruh positif dan signifikan terhadap kinerja karyawan, sehingga ketika gaya kepemimpinan meningkat maka kinerja karyawan juga ikut meningkat.

Sistem gaya kepemimpinan belum sesuai dengan harapan karyawan, dimana ketidaksesuaian ini juga berpengaruh terhadap loyalitas karyawan. Masih ada karyawan yang belum menunjukkan loyalitasnya terhadap perusahaan, dan masih banyaknya karyawan yang tidak mengikuti peraturan yang sudah ditetapkan oleh perusahaan, contohnya seperti masih banyak karyawan yang tidak datang tepat waktu dan jarang mengikuti apel pagi. Hal tersebut tentu saja dapat menghambat pencapaian perusahaan. Secara empires, gaya kepemimpinan berpengaruh positif dan signifikan terhadap loyalitas karyawan, sehingga ketika gaya kepemimpinan meningkat maka loyalitas karyawan juga ikut meningkat.

Loyalitas karyawan yang kurang maksimal juga dipengaruhi oleh kinerja karyawan dimana sikap dan pola pikir karyawan berperan dalam menentukan prestasi kerja. Masih kurangnya kinerja karyawan pada PT. Fastrata Buana cabang Pulogadung berdampak pula terhadap prestasi kerja para karyawannya. Sebagai contoh kurangnya disiplin karyawan dapat menyebabkan pekerjaan tidak selesai sesuai deadline yang sudah ditentukan, sikap kurang terbukannya antara karyawan dengan atasan dapat menyebabkan adanya kendala pekerjaan yang tidak terpecahkan dengan tepat, dan kurangnya komunikasi dan kerja sama antar karyawan membuat mereka tidak terbuka akan inovasi dan kreatifitas karyawan. Dan tentu saja hal tersebut dapat menghambat pencapaian/ tujuan perusahaan, sehingga kinerja yang ditampilkan 


\section{JURNAL EKOBIS: EKONOMI, BISNIS \& MANAJEMEN} Vol 9 Nomor 1 (2019)

karyawan belum maksimal. Setelah dilakukan pengujian secara empires, kinerja karyawan juga berpengaruh positif dan signifikan terhadap loyalitas karyawan, sehingga apabila kinerja karyawan meningkat maka loyalitas karyawan juga akan ikut meningkat.

Berdasarkan hasil pengujian empires pada hipotesis keempat, terdapat pengaruh tidak langsung variabel gaya kepemimpinan terhadap loyalitas karyawan melalui kinerja karyawan, artinya gaya kepemimpinan berpengaruh positif dan signifikan secara tidak langsung terhadap loyalitas karyawan.

Adapun saran dari hasil penelitian, pada faktor gaya kepemimpinan masih perlu meningkatkan perhatian dan rasa peduli seorang atasan kepada karyawannya, khususnya memberikan motivasi kepada karyawan dan juga memberikan apa yang dibutuhkan oleh karyawan sehingga karyawan akan merasa lebih puas dalam bekerja dan akan lebih meningkatkannya kinerjanya. Pada faktor Kinerja karyawan selain dengan meningkatkan rasa kepeduliaan dan motivasi atasan kepada karyawan, tentu saja perusahaan perlu juga untuk melakukan pelatihan dan training kepada para karyawan agar pengetahuan karyawan semakin bertambah, sehingga ide kreatifitas dan inovasinya dapat ter explore. Pada faktor loyalitas karyawan perlu meningkatkan komunikasi baik antara atasan dengan karyawan maupun karyawan dengan karyawan lainnya, sehingga mereka bisa saling bertukar pikiran atau ide ketika sedang menghadapi masalah dalam pekerjaan. Selain itu perusahaan juga harus meningkatkan peraturan agar karyawan dapat lebih disiplin baik dalam absensi maupun dalam menyelesaikan pekerjaan.

Untuk penelitian yang akan dating, diharapkan adanya variabel lain yang dapat mempengaruhi loyalitas karyawan selain gaya kepemimpinan dan kinerja karyawan.

\section{REFERENSI}

Abdilah. 2011. Analisis Pengaruh Gaya Kepemimpinan Dan Motivasi Kerja Terhadap Kinerja Karyawan (Studi Pada Karyawan Badan Kesatuan Bangsa Politik Dan Perlindungan Masyarakat Provinsi Jawa Tengah).

Emilia Ika Andriyani. 2016. Pengaruh Gaya Kepemimpinan Terhadap Kinerja Karyawan.

Guntoro. (2015). "Pengaruh Gaya Kepemimpinan Demokratis Terhadap Kinerja Pegawai Pada

Kantor Unit Pelaksana Teknis Dinas (UPTD) Balai Pengembangan Dan Pelatihan Pendidikan Non Formal Informal Kalimantan Tengah. Skripsi. Fakultas Ilmu Sosial Dan Ilmu Politik Program Studi Administrasi Negara. Universitas Muhammadiyah Palangkaraya.

Mar'atussholihah, Heni. 2010. "Hubungan antara Loyalitas Kerja Karyawan dengan Iklim Organisasi Positif". Skripsi. Yogyakarta: Fakultas Ilmu Sosial dan Humaniora.

Pratama, Christian Yogi. (2012). Pengaruh Gaya Kepemimpinan Otokratis Terhadap Kepuasan Kerja. Jurusan Psikologi, Fakultas Ilmu Pendidikan, Universitas Negeri Semarang, Indonesia.

Rivai, Veithzal. 2004. "Manajemen Sumber Daya Manusia Untuk Perusahaan, Cetakan Pertama, Jakarta, PT. Raja Grafindo Persada.

Robbins, Stephen. P. 2006. Perilaku organisasi. Edisi Bahasa Indonesia. Jakarta: Indeks.

Safitri, Rahmadana (2015), "PengaruhKompensasi Terhadap Loyalitas Karyawan PT. Putera Lautan Kumala Lines Samarinda", eJournal Administrasi Bisnis, Universitas Mulawarman (online) 15 April 2016, laman <ejournal.adbisnis.fisip -unmul.ac.id>.

Tampi, Bryan Johannes. 2014. Pengaruh Gaya Kepemimpinan dan Motivasi Terrhadap Kinerja Karyawan pada PT. Bank Negara Indonesia, Tbk (Regional Sales Manado). Journal "Acta Diurna" Volume III. No.4. Tahun 2014.

Wati, Lela Nurlaela. 2018. "Metodologi Penelitian Terapan, Aplikasi SPSS, Eviews, Smart PLS dan AMOS”. Penerbit CV. Pustaka Amri: Bekasi Barat. 